This item was submitted to Loughborough's Research Repository by the author.

Items in Figshare are protected by copyright, with all rights reserved, unless otherwise indicated.

\title{
Permeate flux and fouling resistance in ultrafiltration of depectinized apple juice using ceramic membranes
}

PLEASE CITE THE PUBLISHED VERSION

http://dx.doi.org/10.1016/S0260-8774(03)00044-X

PUBLISHER

(C) Elsevier

VERSION

AM (Accepted Manuscript)

LICENCE

CC BY-NC-ND 4.0

\section{REPOSITORY RECORD}

Vladisavljevic, Goran T., P. Vukosavljevic, and B. Bukvic. 2012. "Permeate Flux and Fouling Resistance in Ultrafiltration of Depectinized Apple Juice Using Ceramic Membranes". figshare.

https://hdl.handle.net/2134/10580. 
This item was submitted to Loughborough's Institutional Repository (https://dspace.lboro.ac.uk/) by the author and is made available under the following Creative Commons Licence conditions.

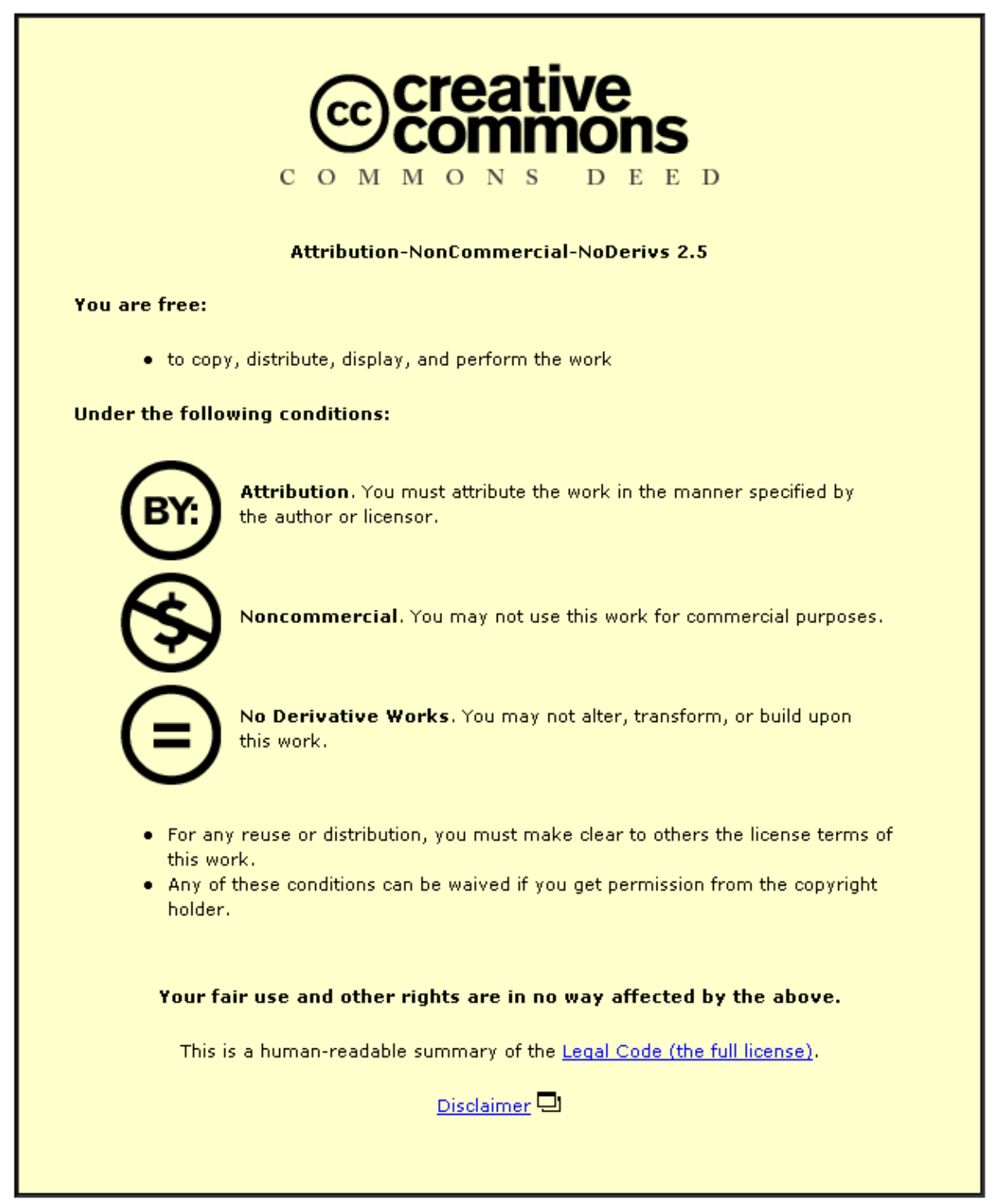

For the full text of this licence, please go to: http://creativecommons.org/licenses/by-nc-nd/2.5/ 


\title{
Permeate flux and fouling resistance in ultrafiltration of depectinized apple juice using ceramic membranes
}

\author{
G.T. Vladisavljević* , P. Vukosavljević, B. Bukvić \\ Institute of Food Technology and Biochemistry, Faculty of Agriculture, University of \\ Belgrade, P.O. Box 127, YU-11081 Belgrade-Zemun, Serbia, Yugoslavia
}

\begin{abstract}
Raw depectinized apple juice was clarified in a laboratory scale ultrafiltration (UF) system using ceramic tubular membranes (Tech-Sep Carbosep) with a molecular weight cut-off of 300,000, 50,000, and 30,000 daltons. The experiments have been carried out over a wide range of transmembrane pressures $(100-400 \mathrm{kPa})$, temperatures $\left(20-55^{\circ} \mathrm{C}\right)$, and feed flow rates (100-900 mL/min). Permeate flux significantly decreased with time until a steady state was established. The steady-state permeate flux reached a maximum at a transmembrane pressure of about $200 \mathrm{kPa}$. Higher permeate flux was obtained at higher temperatures due to lower permeate viscosity. The steady-state permeate flux was proportional to the feed flow rate raised to powers ranging between 0.22 and 0.31 . All the membranes studied produced the clarified juice with a satisfactory clarity and color intensity value.
\end{abstract}

Key words: ultrafiltration, apple juice, juice clarification, ceramic membrane, permeate flux.

${ }^{*}$ Corresponding author. Tel. + 381-11-615-315; fax: +381-11-199-711.

E-mail address: gtvladis@afrodita.rcub.bg.ac.yu (G. Vladisavljević). 


\section{Introduction}

Application of ultrafiltration (UF) to the clarification of fruit and vegetable juices has been extensively studied during the last 25 years. Heatherbell, Short, \& Strubi (1977) introduced UF to clarify apple juice and obtained a stable clear product. UF has also been investigated for the clarification of pear (Kirk, Montgomery, \& Kortekaas, 1983), orange and lemon (Capannelli, Bottino, Munari, Lister, Maschio, \& Becchi, 1994), starfruit (Sulaiman, Sulaiman, \& Yih, 1998), kiwifruit (Wilson \& Burns, 1983), guava (Chan \& Chaing, 1992), pineapple (Jiraratananon, Uttapap, \& Tangamornsuksun, 1997), and passion (Jiraratananon \& Chanachai, 1996) juice. Besides that, UF has been used in conjunction with ion-exchange resins to deacidify passion juice (Lue \& Chiang, 1989) and to debitter grapefruit juice and grapefruit pulp (Hernandez, Couture, Rouseff, Chen, \& Barros, 1992).

Compared to the conventional clarification process, UF can bring the following benefits: (1) eliminate the use of diatomaceous earth, thereby, reducing production costs and the problem of waste treatment; (2) improve the clarity of the juice; (3) increase the product yield; (4) reduce labor costs; and (5) allow enzyme recovery for potential reuse, thereby reducing total enzyme consumption to about 1/3 (Rösch, 1985).

Membrane clarification of juices has been studied using membrane modules of different configurations, such as tubular (Alvarez, Andres, Riera, \& Alvarez, 1996), plate-and-frame (Sheu, Wiley, \& Schlimme, 1987), spiral wound (Wu, Zall, \& Tzeng, 1990), and hollow fiber (Constenla \& Lozano, 1996), as well as dead-end or stirred batch cells (Riedl, Girard, \& Lencki, 1998, Sulaiman et al., 1998). These studies have been carried out using ceramic (Alvarez et al., 1996), metallic (Barefoot, Tai, Brandon, \& Thomas, 1989), and polymeric membranes made of polysulfone, polyamide, fluoropolymers, polypropylene, etc. 
The main problem in practical applications of UF is the reduction of permeate flux with time, caused by the accumulation of feed components in the pores (membrane fouling) and on the membrane surface (concentration polarization and gel formation). In order to control membrane fouling during juice clarification, several flux enhancement methods have been proposed such as periodic gas backwashing with air or $\mathrm{N}_{2}$ (Su, Liu, \& Wiley, 1993), permeate backwashing by pulsating entry flow (Ben Amar, Gupta, \& Jaffrin, 1990; Padilla \& McLellan, 1993), and enzymatic treatment before UF (Alvarez, Alvarez, Riera, \& Coca, 1998).

UF can be modeled using osmotic pressure theories, employing thermodynamical principles governing true solution behavior (Koutake, Matsuno, Nabetani, Nakajima, \& Watanabe, 1993) or hydrodynamic theories based on the premise that a cake forms on the membrane surface, which offers a hydrodynamic resistance to permeate flow (Fane \& Fell, 1987). Osmotic pressure models are traditionally used for UF of small solute particles and macromolecules that does not lead to formation of a gel layer on the membrane surface. However, in UF of fruit juice hydrodynamic or filtration theories are commonly used, since a cake or a gel layer is formed. According to a constant pressure UF theory, the permeate flux (J) is expressed by the resistance-in-series model:

$$
\mathrm{J}=\Delta \mathrm{p} /\left(\mu \mathrm{R}_{\mathrm{t}}\right)
$$

where $\Delta \mathrm{p}$ is the transmembrane pressure, $\mu$ the permeate viscosity, and $\mathrm{R}_{\mathrm{t}}$ the total hydraulic resistance defined in this paper by (Jiraratananon, Uttapap, \& Sampranpiboon, 1998):

$$
\mathrm{R}_{\mathrm{t}}=\mathrm{R}_{\mathrm{m}}+\mathrm{R}_{\mathrm{f}}=\mathrm{R}_{\mathrm{m}}+\mathrm{R}_{\mathrm{ef}}+\mathrm{R}_{\mathrm{if}}
$$

where $R_{m}$ is the hydraulic resistance of clean membrane and $R_{f}$ the total (overall) fouling resistance $\left(R_{f}=R_{e f}+R_{i f}\right)$. Here, the external fouling resistance $\left(R_{e f}\right)$ includes concentration polarization and deposition of solids on the membrane surface. The internal fouling resistance $\left(\mathrm{R}_{\mathrm{if}}\right)$ is due to internal fouling inside the pores. 
The main objective of this work is to study the effect of operating parameters such as transmembrane pressure, feed flow rate through the module, and temperature on the permeate flux and fouling resistance in apple juice UF. The experiments have been carried out using commercial ceramic membranes in a batch mode of operation with total retentate recycle and continuous removal of the permeate stream. Ceramic membranes hold many advantages over polymeric membranes such as thermal and chemical tolerance, resistance to abrasion and high mechanical strength.

\section{Materials and methods}

\subsection{Apple juice}

Apple juice used in this work was made from a mix of different apples (Jonagold, Idared, Golden Delicious, etc). Before UF, depectinization was performed at $55{ }^{\circ} \mathrm{C}$ for 1 hour by adding $0.1 \%$ (w/w) of pectinase (Gamma Chemie GmbH, München, Germany). The juice was then subjected to a centrifugal separation to remove enzyme molecules and large haze particles. Until further use the juice was stored in a stainless steel tank at the $\mathrm{CO}_{2}$ gauge pressure of $200 \mathrm{kPa} .0 .5 \%$ (w/w) potassium sorbate was added as a preservative.

\subsection{Membranes}

The experiments were performed with three tubular inorganic UF membranes produced by Tech-Sep (Rhône-Poulenc Group, Miribel, France), type Carbosep M9, M8, and M7. These anisotropic membranes are made with an inner diameter of $6 \mathrm{~mm}$ and a molecular weight cut-off of 300,000, 50,000 and 30,000 daltons, respectively. Carbosep membranes are 
composed of thin permselective skin of zirconium oxide and titanium dioxide supported by a porous carbon substructure. The membranes were installed inside a cylindrical stainless steel module with an effective membrane length of $225 \mathrm{~mm}$ and an effective membrane area of $42.4 \mathrm{~cm}^{2}$. The membrane was cleaned after each experiment with a hot $1 \%(\mathrm{w} / \mathrm{w})$ aqueous solution of $\mathrm{NaOH}$ and $1 \mathrm{mg} / \mathrm{L} \mathrm{NaClO}$ solution for about $30 \mathrm{~min}$. The acid cleaning was not used because no improvement in permeate flux recovery was observed.

\subsection{Experimental set-up and procedure}

The schematic view of the experimental setup is shown in Fig. 1. The feed juice in the amount of 1.5-2 L was recycled between the retentate reservoir and the module by a rotary pump and the feed flowrate was controlled with a laboratory made rotameter. Temperature in the system $\left(20-55^{\circ} \mathrm{C}\right)$ was adjusted by passing the juice stream from a bypass line through the thermostat bath. Transmembrane pressure was controlled by the back-pressure valve. The permeate (clear juice) was collected in a reservoir placed on a digital balance. The mass of permeate collected was measured with an accuracy of \pm 0.1 g every 1 min for periods of 120 min. The cumulative permeate volume was in the range of 30-150 and 130-280 mL at 20 and $55^{\circ} \mathrm{C}$, respectively. Therefore, the volume concentration factor (VCR) at the end of each run ranged between 1.02 and 1.2. The flow rate through the membrane tube was in the range of $100-900 \mathrm{~mL} / \mathrm{min}$, which was equivalent to a mean velocity of $0.06-0.5 \mathrm{~m} / \mathrm{s}$. It corresponds to the tube Reynolds number of $240-2200$ at $20^{\circ} \mathrm{C}$ and $390-3500$ at $50^{\circ} \mathrm{C}$.

\section{Results and discussion}

\subsection{Influence of operating conditions on the permeate flux}


The cumulative permeate volume as a function of time for Carbosep M7 membrane at different pressures, temperatures and feed flow rates is shown in Fig. 2. Similar dependencies were also obtained for M7 and M8 membranes. The permeate volume collected during UF of apple juice increased with time but at a decreasing rate. Besides that, the permeate volume collected at any time increased with transmembrane pressure, temperature and feed flow rate in the investigated range of operating parameters. The lower permeation rates for apple juice in comparison with those of water were due to membrane fouling.

The permeate volume collected during UF of pure water increased linearly with time, which is in accordance with Eqs. (1) and (2). In that case $\mathrm{R}_{\mathrm{t}}=\mathrm{R}_{\mathrm{m}}=$ const throughout the whole operation and $\mathrm{J}=$ const at $\Delta \mathrm{p}=$ const. The $\mathrm{R}_{\mathrm{m}}$ values estimated from the slopes of $\mathrm{V} v \mathrm{vs}$. $\tau$ lines were $6.7,6.5$, and $40 \times 10^{12} 1 / \mathrm{m}$ for M7, M8, and M9 membrane, respectively.

Experimental data corresponding to the permeate flux decline for the Carbosep M7 membrane are presented in Fig. 3. Flux values were obtained by numerical differentiation of the mass versus time data collected during each experiment. The measurement of mass and time was started 10-20 s after the beginning of the experiments, which was time interval necessary to adjust a required transmembrane pressure. According to Lahoussine-Turcaud, Wiesner, \& Bottero (1990), the flux curve can be devided in two domains. Domain 1 corresponds to the initial flux decline for $t \rightarrow 0$ and it involves internal fouling. Domain 2 corresponds to the remaining flux decline for $\mathrm{t} » 0$ and is believed to involve external membrane fouling (Mondor, Girard, \& Moresoli, 2000). In Fig. 3, the initial flux decline (in the first $10-20 \mathrm{~s}$ ) was $50-74 \%$ of the total flux decline. The steady state was established after 55-94 min of operation and the steady-state permeate fluxes were $27-53 \%$ of their initial values. Contrary to this, the permeate flux during UF of a silica sol and protein solutions dropped to a steady-state value in a matter of seconds (Chudacek and Fane, 1984). 
It should be noted that the initial permeate flux was independent on the feed flow rate in the membrane tube. It could be explained by the fact that in the early stage of UF, permeate flux is controlled by the internal fouling, which is not significantly influenced by the feed flow rate. The steady state permeate flux was, however, higher at the higher feed flow rate, which is in accordance with the film model (Fane \& Fell, 1987).

The effect of transmembrane pressure, $\Delta \mathrm{p}$, on steady-state permeate flux, $\mathrm{J}_{\mathrm{s}}$ is shown in Fig. 4. The permeate flux increased initially with the applied transmembrane pressure, and then decreased with continued increase in the transmembrane pressure. The point at which the permeate flux was maximal was the optimum transmembrane pressure. In our experiments this optimum occurred at $160-240 \mathrm{kPa}$ and decreased with feed stream flow rate. The optimum $\Delta \mathrm{p}$ value of $160 \mathrm{kPa}$ for Carbosep M8 membrane at $800 \mathrm{~mL} / \mathrm{min}$ is in excellent agreement with $157 \mathrm{kPa}$ reported by Kirk et al. (1983) for pear juice UF, $154 \mathrm{kPa}$ reported by Sulaiman et al. (1998) for starfruit juice UF, and 140-145 kPa reported by Rao, Acree, Cooley, \& Ennis (1987) for apple juice UF using polysulfone hollow fibers. However, the optimum transmembrane pressures in this work were somewhat higher than $117 \mathrm{kPa}$, found by Jiraratananon \& Chanachai (1996) for UF of passion fruit juice at $50{ }^{\circ} \mathrm{C}$.

The bell-shaped permeate flux-pressure behavior for UF of apple juice is in contrast to what many investigators have found for protein solutions (Do \& Elhassadi, 1985) and colloidal inorganic oxide dispersions (e.g., Vladisavljević, Milonjić, Nikolić, \& Pavasović, 1992; Vladisavljević, Milonjić, \& Pavasović, 1995). Permeate flux of protein solutions and colloidal inorganic oxide dispersions continued to increase but at a decreasing rate with transmembrane pressure until it reached a constant limiting value.

However, it must be noted that pectic substances and suspended juice solids have physical characteristics different from proteins and inorganic oxide particles. Proteins can be regarded as rigid globular molecules. When a gel layer of protein builds up, the spherical 
shape leaves spaces for passage of the permeate. On increasing transmembrane pressure these spaces never become completely closed, thus allowing the permeate to pass through to give a flux plateau above the optimum $\Delta \mathrm{p}$ value. On the other hand, haze particles of apple juice are chain-like aggregates of polymerized polyphenol and/or polyphenol-protein complexes (Beveridge \& Tait, 1993). At a sufficiently high transmembrane pressure, these large aggregates are disrupted into much smaller particles forming a less porous and more resistive gel. Similar to that, pectic substances are chain-like macromolecules of galacturonic acid units aggregated by hydrogen bond bridges. Kirk et al. (1983) have suggested that when pectic gel layer is compressed, these bridges could collapse leading to the closure of interstitial spaces between the chains. They reported that the pectic gel layer is elastic as evidenced by the partial restoration of permeate flux upon gradual release of the transmembrane pressure.

Fig. 5 indicates that $\log$ (steady-state permeate flux) increases in proportion to $\log ($ feed flow rate) for all three Carbosep membranes, i.e.:

$$
\mathrm{J}_{\mathrm{s}}=\mathrm{AQ}_{\mathrm{f}}^{\mathrm{B}}
$$

The power law parameters A and B in Eq. (3) were obtained by the nonlinear least-squares regression of the plots in Fig. 5 (Table 1). The exponent on feed flow rate ranges between 0.22 and 0.31 which is in a good agreement with 0.33 anticipated by Lévêque (1928) for heat transfer in laminar flow channels. On the other hand, the B values in Table 1 are lower than 0.54 obtained by Charcosset \& Choplin (1996) for UF of pectin solutions under laminar flow conditions using Carbosep M8 membrane. In this work, however, pectin content in the feed juice after depectinization was only $7 \mathrm{mg} / \mathrm{L}$.

The effect of temperature on permeate flux for the three Carbosep membranes at a transmembrane pressure of $200 \mathrm{kPa}$ and a feed flow rate of $800 \mathrm{~mL} / \mathrm{min}$ is illustrated in Fig. 6. An increase of temperature from 20 to $55{ }^{\circ} \mathrm{C}$ enhanced permeate flux due to an increase of mass-transfer coefficient according to the film model (Fane \& Fell, 1987). For Carbosep M9 
membrane, the permeate flux increased linearly with temperature at a rate of $0.23 \mathrm{~L} /\left(\mathrm{m}^{2} \mathrm{~h}\right)$ for each $1^{\circ} \mathrm{C}$. It is in contrast to what Jiraratananon \& Chanachai (1996) have found for passion fruit juice. They observed a drop of permeate flux by increasing temperature from 40 to $50{ }^{\circ} \mathrm{C}$ due to gelatinization at the membrane surface caused by cross-linking between deposited pectin and starch molecules. A downside to the use of higher temperatures during apple juice UF may be a larger post-bottling haze formation (Tajchakavit, Boye, \& Couture, 2001).

\subsection{Influence of operating conditions on the fouling resistance}

Influence of feed flow rate on the total and fouling resistance for M7 and M9 membrane is shown in Figs. 7 and 8. These resistances were determined from the steady-state permeate fluxes and $R_{m}$ values using Eqs. (1) and (2). Both $R_{t}$ and $R_{f}$ decreased with feed flow rate because an increase in flow rate enhanced mass transfer coefficient and reduced concentration polarization and accumulation of retained solutes on the membrane surface. In the case of less resistive M7 membrane, the fouling resistance was the major resistance to permeate flow over the whole range of feed flow rate investigated. For more resistive M9 membrane, however, $R_{f}$ controlled the permeate flux at a feed flow rate below $260 \mathrm{~mL} / \mathrm{min}$, while at the higher feed flow rates, the permeate flux was controlled by the membrane resistance, $\mathrm{R}_{\mathrm{m}}$.

Fig. 9 shows the relative magnitude of fouling resistance as a function of transmembrane pressure for M7 membrane. The steady-state fouling resistance increased with transmembrane pressure and at $400 \mathrm{kPa}$, reached more than $93 \%$ of the total resistance. For small transmembrane pressures, e.g. $100 \mathrm{kPa}$, the fouling resistance significantly decreased with increasing the feed flow rate, which was due to a higher rate of solute back-transfer. At relatively high operating pressures (above $300 \mathrm{kPa}$ for the conditions as in Fig. 9), the steadystate fouling resistance, i.e. permeate flux was virtually independent on the feed flow rate. 
Under these conditions, permeate flux was limited by the dense structure of the deposited fouling layer.

\subsection{Influence of UF on chemical composition of the apple juice}

Influence of clarification process on juice composition is shown in Table 2. The titratable acids and sugars content of the juice were not affected by the process. These parameters were, respectively, about $0.45 \%$ malic acid and $98 \mathrm{~g} / \mathrm{L}$. According to the European regulations, the clarified juice presented a satisfactory clarity (transparency at $625 \mathrm{~nm}$ more than $80 \%$ ) and color intensity (transparency at $420 \mathrm{~nm}$ more than $30 \%$ ) value in all the cases. The highest clarity and the lowest color intensity value for the juice clarified using M7 membrane can be explained by the smallest molecular weight cut-off of that membrane. Due to the same fact, the total phenolics content in the permeate of M7 membrane was the lowest.

\section{Conclusion}

Ceramic tubular UF membranes with 300,000, 50,000, and 10,000 dalton molecular weight cut-off were successfully used to clarify depectinized apple juice. Decline in permeate flux over time was attributed to the formation of a layer of retained juice solids on the surface of the membrane that increased overall hydraulic resistance. The fouling resistance decreased with feed flow rate at a transmembrane pressure below $300 \mathrm{kPa}$. In the case of less resistive M7 membrane, the fouling resistance was the major resistance to permeate flow over the whole range of feed flow rate investigated. For more resistive M9 membrane, however, the fouling resistance controlled the permeate flux only at a feed flow rate less than $260 \mathrm{~mL} / \mathrm{min}$. The steady-state permeate flux increased with transmembrane pressure until it reached a 
maximum value at $\Delta \mathrm{p}$ of about $200 \mathrm{kPa}$ and then decreased with further increase in $\Delta \mathrm{p}$. The observed decrease in permeate flux after reaching a maximum value was probably due to the disruption of large aggregates of haze particles into much smaller particles forming a less porous and more resistive gel layer.

\section{References}

Alvarez, V., Andres, L. J., Riera, F. A., \& Alvarez, R. (1996). Microfiltration of apple juice using inorganic membranes: process optimization and juice stability. Canadian Journal of Chemical Engineering, 74, 156-162.

Alvarez, S., Alvarez, R., Riera, F. A., \& Coca, J. (1998). Influence of depectinization on apple juice ultrafiltration. Colloids and Surfaces A: Physicochemical and Engineering Aspects, 138, 377-382.

Barefoot, S. F., Tai, H. Y., Brandon, S. C., \& Thomas, R. L. (1989). Production of microbiologically stable apple juice by metallic membranes ultrafiltration. Journal of Food Science, 54, 408-411.

Ben Amar, R., Gupta, B. B., \& Jaffrin, M. Y. (1990). Apple juice clarification using mineral membranes: fouling control by backwashing and pulsating flow. Journal of Food Science, 55, $1620-1625$.

Beveridge, T. \& Tait, V. (1993). Structure and composition of apple juice haze. Food Structure, 12, 195-198. 
Capannelli, G., Bottino, A., Munari, S., Lister, D. G., Maschio, G., \& Becchi, I. (1994). The use of membrane processes in the clarification of orange and lemon juices. Journal of Food Engineering, 21, 473-483.

Chan, W. Y., \& Chaing, B. H. (1992). Production of clear guava nectar. International Journal of Food Science and Technology, 27, 435.

Charcosset, C. \& Choplin, L. (1996). Ultrafiltration of non-newtonian fluids. Journal of Membrane Science, 115, 147-160.

Chudacek, M.W. \& Fane, A.G. (1984). The dynamics of polarization in unstirred and stirred ultrafiltration. Journal of Membrane Science, 21, 145-160.

Constenla, D. T. \& Lozano, J. E. (1996). Predicting stationary permeate flux in the ultrafiltration of apple juice. Lebensmittel-Wissenschaft und Technologie, 29, 587-592.

Do, D. D. \& Elhassadi, A .A. (1985). A theory of limiting flux in a stirred batch cell. Journal of Membrane Science, 25, 113-132.

Fane, A. G. \& Fell, C. J. D. (1987). A review of fouling and fouling control in ultrafiltration. Desalination, 62, 117-136.

Heatherbell, D. A., Short, J. L., \& Strubi, P. (1977). Apple juice clarification by ultrafiltration. Confructa, 22, 157-169.

Hernandez, E., Couture, R., Rouseff, R., Chen, C. S., \& Barros, S. (1992). Evaluation of ultrafiltration and adsorption to debitter grapefruit juice and grapefruit pulp wash. Journal of Food Science, 57, 664-666.

Jiraratananon, R. \& Chanachai, A. (1996). A study of fouling in the ultrafiltration of passion fruit juice. Journal of Membrane Science, 111, 39-48.

Jiraratananon, R., Uttapap, D., \& Tangamornsuksun, C. (1997). Self-forming dynamic membrane for ultrafiltration of pineapple juice. Journal of Membrane Science, 129, 135-143. 
Jiraratananon, R., Uttapap, D., \& Sampranpiboon, P. (1998). Crossflow microfiltration of a colloidal suspension with the presence of macromolecules. Journal of Membrane Science, 140, 57-66.

Kirk, D. E., Montgomery, M. W., \& Kortekaas, M. G. (1983). Clarification of pear juice by hollow fiber ultrafiltration. Journal of Food Science, 48, 1663-1666.

Koutake, M., Matsuno, I., Nabetani, H., Nakajima, M., \& Watanabe A. (1993). Osmotic pressure model of membrane fouling applied to the ultrafiltration of whey. Journal of Food Engineering, 18, 313-334.

Lahoussine-Turcaud, V., Wiesner, M. R., \& Bottero, J. Y. (1990). Journal of Membrane Science, 52, 173-190.

Lévêque, M. A. (1928). Les lois de la transmission de chaleur par convection. Ann. Mines Rec. Mem. L’Explotas Mines, 13, 201.

Lue, S. J. \& Chiang, B. H. (1989). Deacidification of passion fruit juice by ultrafiltration and ion-exchange processes. International Journal of Food Science and Technology, 24, 395-401. Mondor, M., Girard, B., \& Moresoli (2000). Food Research International, 33, 539-548.

Padilla-Zakour, O. \& McLellan, M. R. (1993). Optimization and modeling of apple juice cross-flow microfiltration with a ceramic membrane. Journal of Food Science, 58, 369-388.

Rao, M. A., Acree, T. E., Cooley, H. J., \& Ennis, R. W. (1987). Clarification of apple juice by hollow fiber ultrafiltration: fluxes and retention of odor-active volatiles. Journal of Food Science, 52, 375-377.

Riedl, K., Girard, B., \& Lencki, R. W. (1998). Influence of membrane structure on fouling layer morphology during apple juice clarification. Journal of Membrane Science, 139, 155166.

Rösch, E. (1985). Experience with ultrafiltration in the 1984 season. Confructa, 30, 27-30. 
Sheu, M. J., Wiley, R. C., \& Schlimme, D. V. (1987): Solute and enzyme recoveries in apple juice clarification using ultrafiltration. Journal of Food Science, 52, 732-736.

Su, S. K., Liu, J. C., \& Wiley, R. C. (1993). Cross-flow microfiltration with gas backwash of apple juice. Journal of Food Science, 58, 638-641.

Sulaiman, M. Z., Sulaiman, N. M., \& Yih, L. S. (1998). Limiting permeate flux in the clarification untreated starfruit juice by membrane ultrafiltration. Chemical Engineering Journal, 69, 145-148.

Tajchakavit, S, Boye, J. I., \& Couture, R. (2001). Effect of processing on post-bottling haze formation in apple juice. Food Research International, 34, 415-424.

Vladisavljević, G. T., Milonjić, S. K., Nikolić, D., \& Pavasović, V. Lj. (1992). Influence of temperature on the ultrafiltration of silica sol in a stirred cell. Journal of Membrane Science, 66, 9-17.

Vladisavljević, G. T., Milonjić, S. K., \& Pavasović, V. Lj. (1995). Flux decline and gel resistance in unstirred ultrafiltration of aluminium hydrous oxide sols. Journal of Colloid and Interface Science, 176, 491-494.

Wilson, E. L. \& Burns, D. J. W. (1983). Kiwifruit juice processing using heat treatment techniques and ultrafiltration. Journal of Food Science, 48, 1101-1105.

Wu, M. L., Zall, R. R., \& Tzeng, W. C. (1990). Microfiltration and ultrafiltration comparison for apple juice clarification. Journal of Food Science, 55, 1162-1163. 


\section{FIGURE CAPTIONS}

Fig. 1. Schematic view of the experimental setup used in this work (PG - pressure gauge, BPR - back-pressure regulator).

Fig. 2. Permeate volume vs. time for ultrafiltration of apple juice and pure water using Carbosep M7 membrane (every second data point is shown).

Fig. 3. Variation of permeate flux with time for Carbosep M7 membrane (the time $\tau_{\mathrm{s}}$ at which the steady state was established is shown in brackets).

Fig. 4. Effect of transmembrane pressure on steady-state permeate flux at $20^{\circ} \mathrm{C}$ using Carbosep M7, M8, and M9 membranes at different feed flow rate.

Fig. 5. Effect of feed flow rate on steady-state permeate flux for all three membranes.

Fig. 6. Effect of temperature on steady-state permeate flux for all three membranes.

Fig. 7. Effect of feed flow rate in the membrane tube on total and fouling resistance in the steady-state for M9 membrane at $20^{\circ} \mathrm{C}$ and $100 \mathrm{kPa}$.

Fig. 8. Effect of feed flow rate in the membrane tube on total and fouling resistance in the steady-state for M7 membrane at $20^{\circ} \mathrm{C}$ and $100 \mathrm{kPa}$.

Fig. 9. Effect of transmembrane pressure on relative magnitude of steady-state fouling resistance at different feed flow rates (M7 membrane at $\left.20^{\circ} \mathrm{C}\right)$. 


\section{T A B L E S}

\section{Table 1}

Values of parameters A and B in the permeate flux vs. feed flow rate correlations (Eq. 3) at $100 \mathrm{kPa}$ and $20^{\circ} \mathrm{C}$ determined using the least-squares regression analysis method.

\begin{tabular}{cccc}
\hline Membrane & $\mathrm{A}^{*}$ & $\mathrm{~B}^{*}$ & $\begin{array}{c}\text { Correlation } \\
\text { coefficient }\end{array}$ \\
\hline Carbosep M7 & 1.72 & 0.29 & 0.978 \\
Carbosep M8 & 1.30 & 0.31 & 0.987 \\
Carbosep M9 & 1.10 & 0.22 & 0.945 \\
\hline \hline
\end{tabular}

${ }^{*}$ With $\mathrm{J}_{\mathrm{s}}$ in $\mathrm{L} /\left(\mathrm{m}^{2} \mathrm{~h}\right)$ and $\mathrm{Q}_{\mathrm{f}}$ in $\mathrm{mL} / \mathrm{min}$. 


\section{Table 2}

Composition of apple juice after pretreatment (depectinization plus centrifugation) and after clarification (traditional process using fining agents or UF).

\begin{tabular}{|c|c|c|c|c|c|}
\hline \multirow{2}{*}{ Component } & \multirow{2}{*}{$\begin{array}{c}\text { Pre- } \\
\text { treated } \\
\text { raw juice }\end{array}$} & \multicolumn{4}{|c|}{ Clear juice } \\
\hline & & $\begin{array}{l}\text { Traditional } \\
\text { process }\end{array}$ & $\begin{array}{c}\text { UF } \\
\text { M7 membrane }\end{array}$ & $\begin{array}{c}\text { UF } \\
\text { M8 membrane }\end{array}$ & $\begin{array}{c}\text { UF } \\
\text { M9 membrane }\end{array}$ \\
\hline $\begin{array}{c}\text { Total solids } \\
\text { (\%) }\end{array}$ & 10.7 & 10.2 & 10.2 & 10.2 & 10.2 \\
\hline $\begin{array}{l}\text { Sugars } \\
(g / L)\end{array}$ & 99 & 96 & 98 & 98 & 98 \\
\hline $\begin{array}{c}\text { Titratable } \\
\text { acids } \\
\text { expressed as } \\
\text { malic acid (\%) }\end{array}$ & 0.46 & 0.45 & 0.45 & 0.45 & 0.45 \\
\hline $\begin{array}{c}\text { Total } \\
\text { phenolics } \\
(\mathrm{mg} / \mathrm{L})\end{array}$ & 582 & 475 & 420 & 445 & 475 \\
\hline $\begin{array}{l}\text { Pectin } \\
(\mathrm{mg} / \mathrm{L})\end{array}$ & 6.8 & 0 & 0 & 0 & 0 \\
\hline $\begin{array}{c}\text { Color } \\
\text { (transparency at } \\
420 \mathrm{~nm}, \% \text { ) }\end{array}$ & 24 & 51 & 36 & 54 & 54 \\
\hline $\begin{array}{c}\text { Clarity } \\
\text { (transparency at } \\
625 \mathrm{~nm}, \% \text { ) }\end{array}$ & 75 & 95 & 96 & 94 & 92 \\
\hline
\end{tabular}




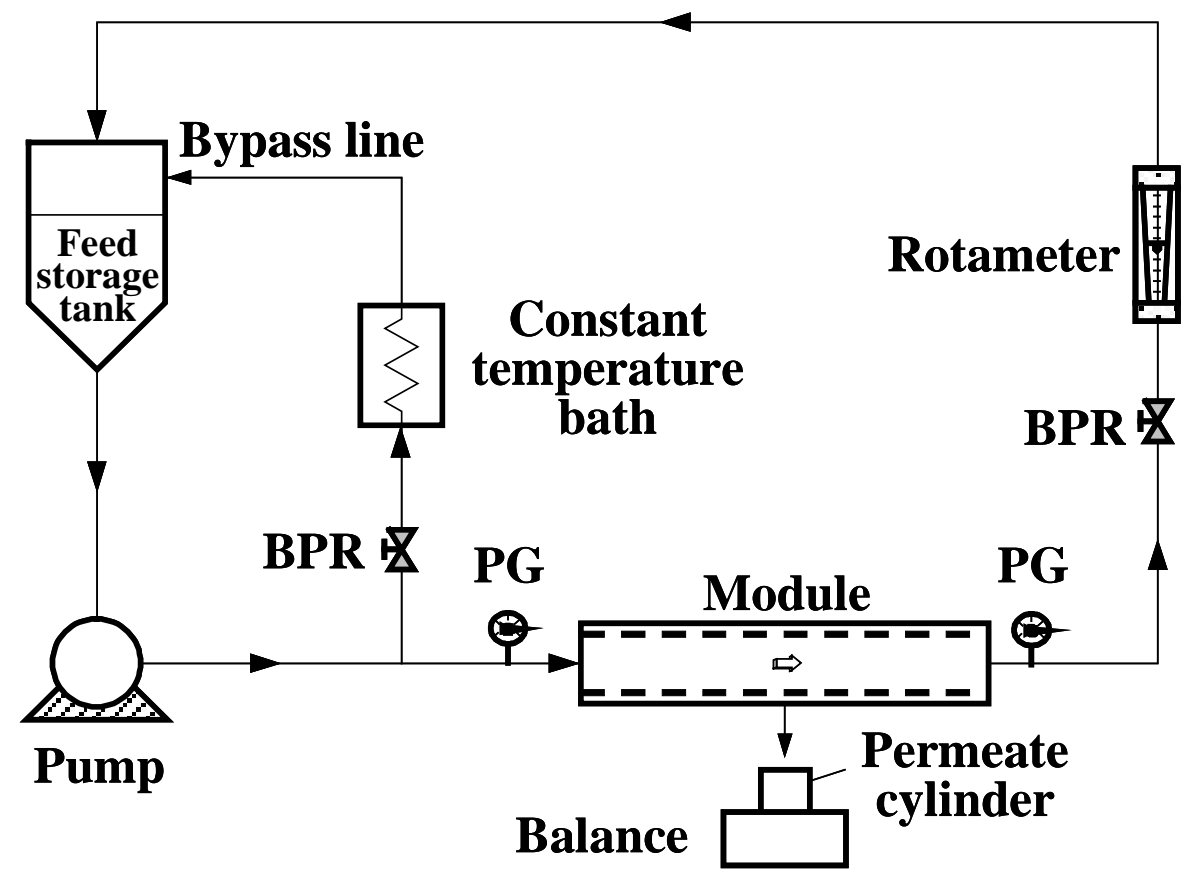

Figure 1. 


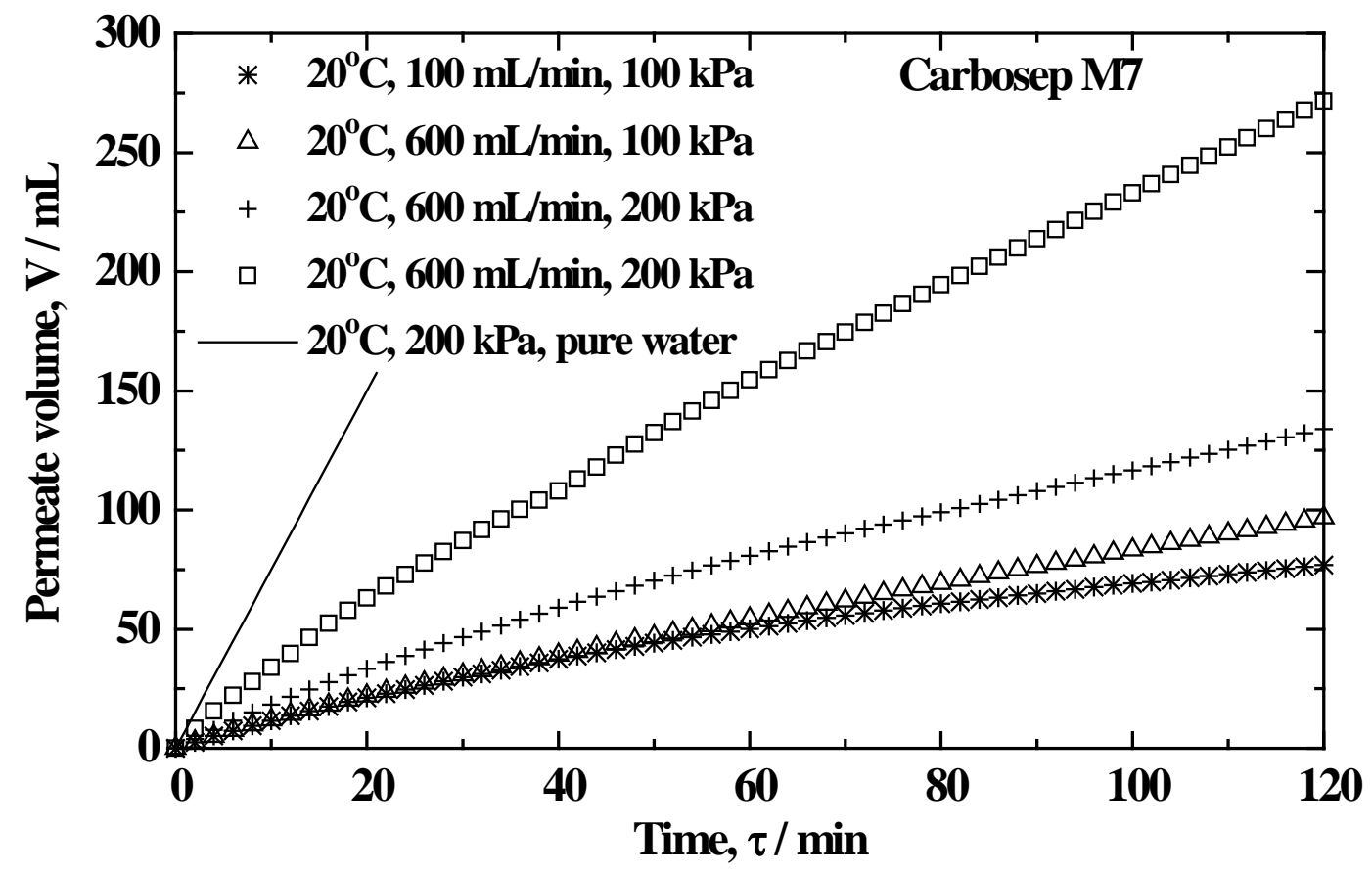

Figure 2. 


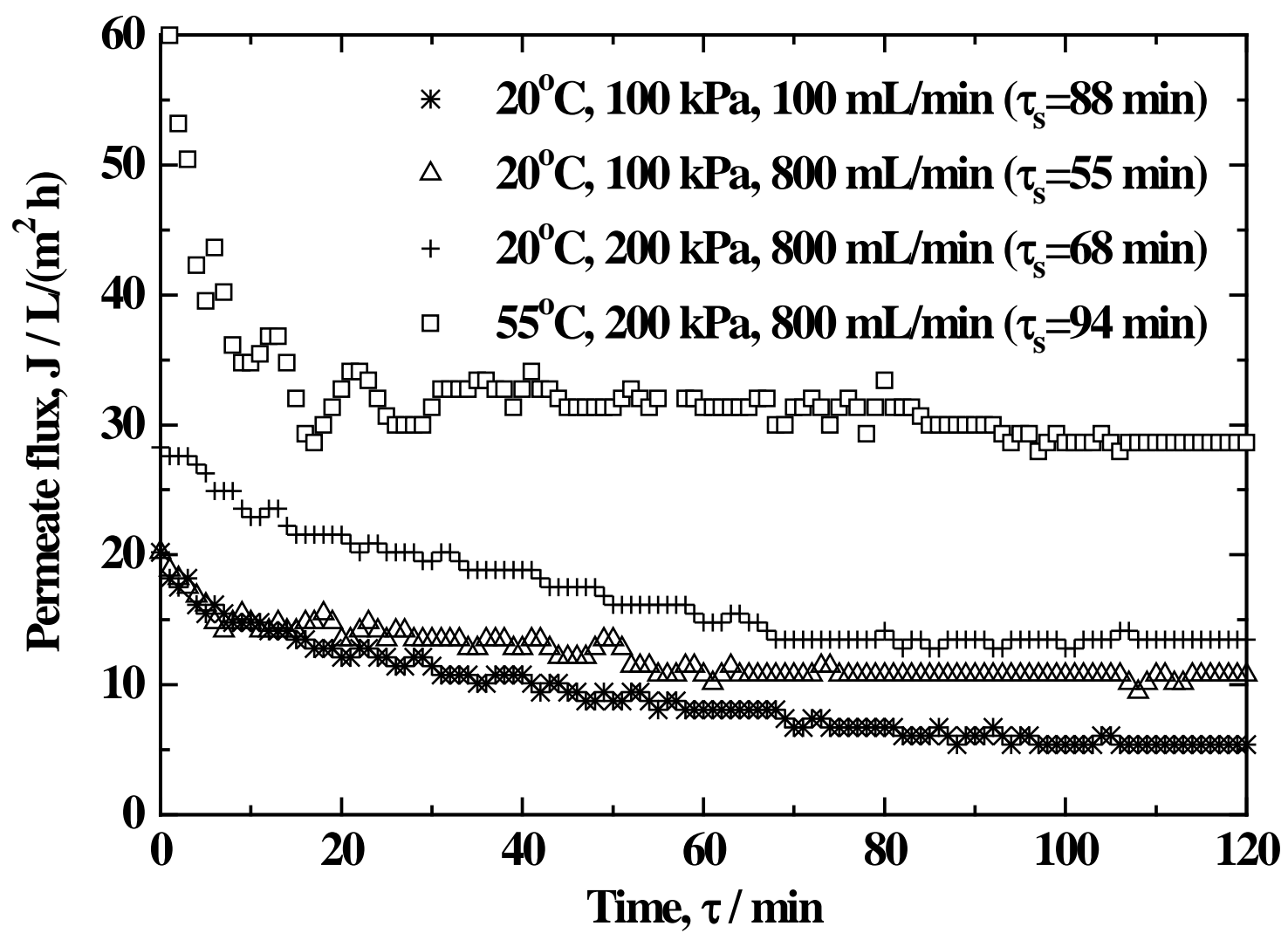

Figure 3. 


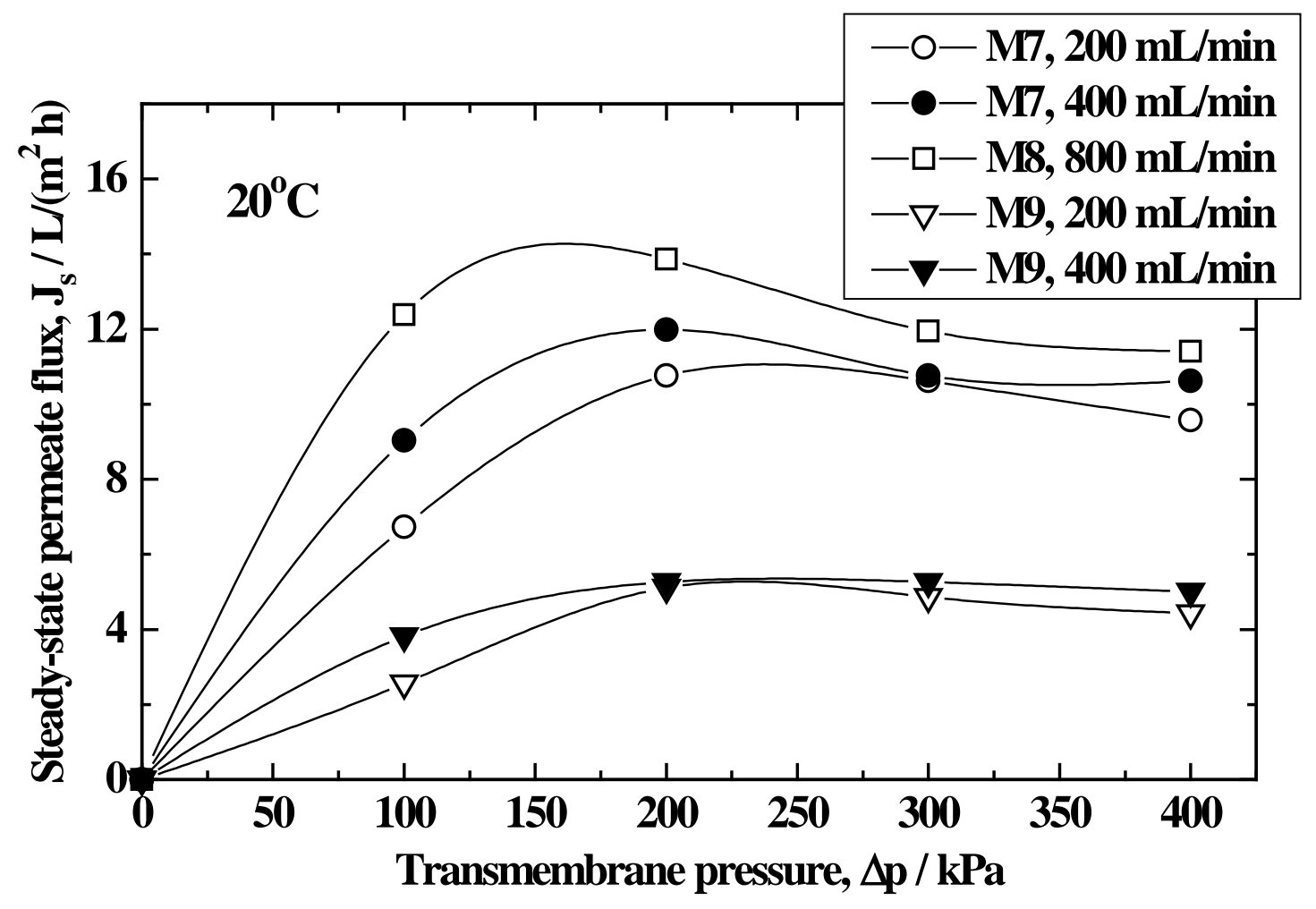

Figure 4. 


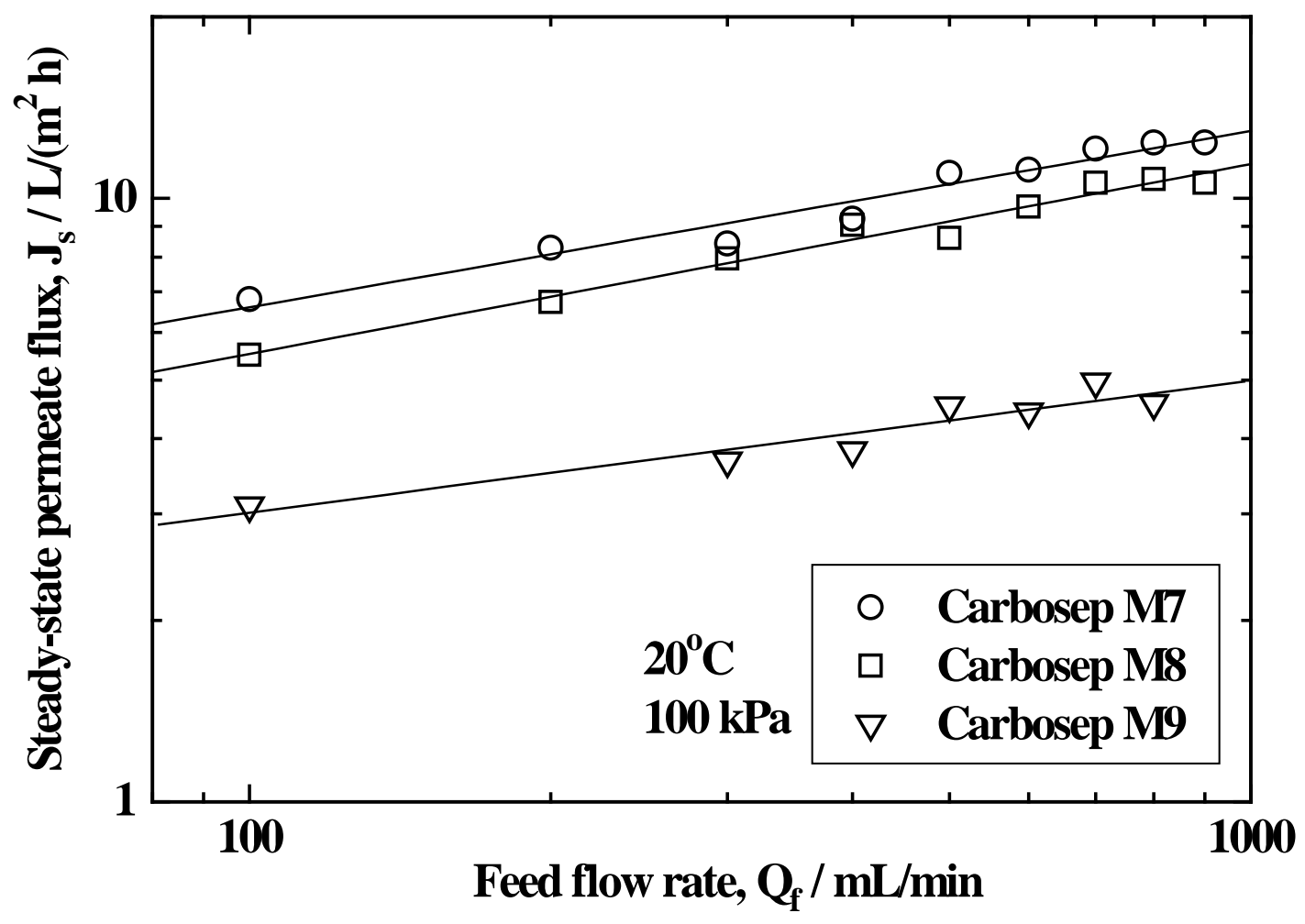

Figure 5. 


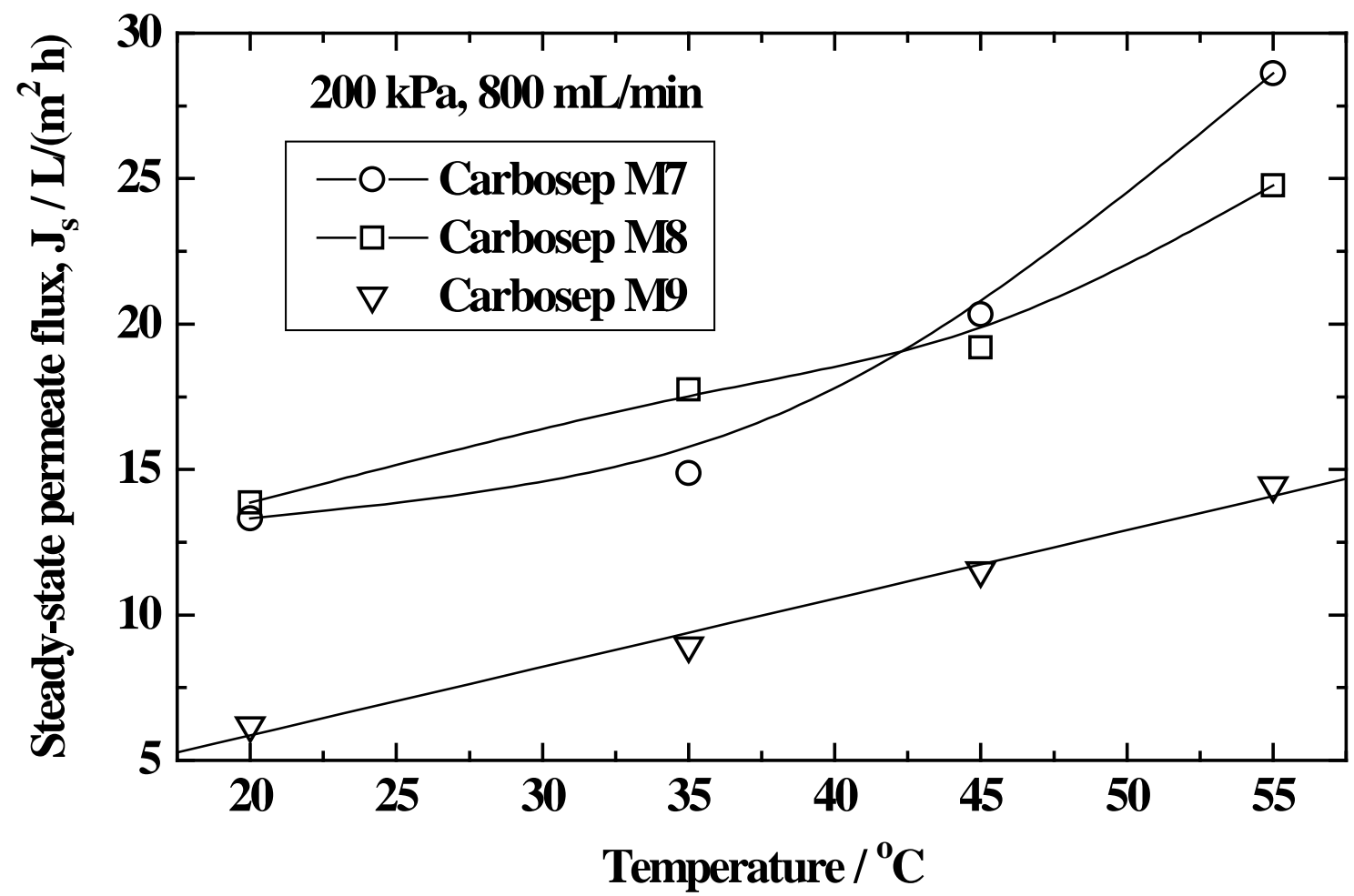

Figure 6. 


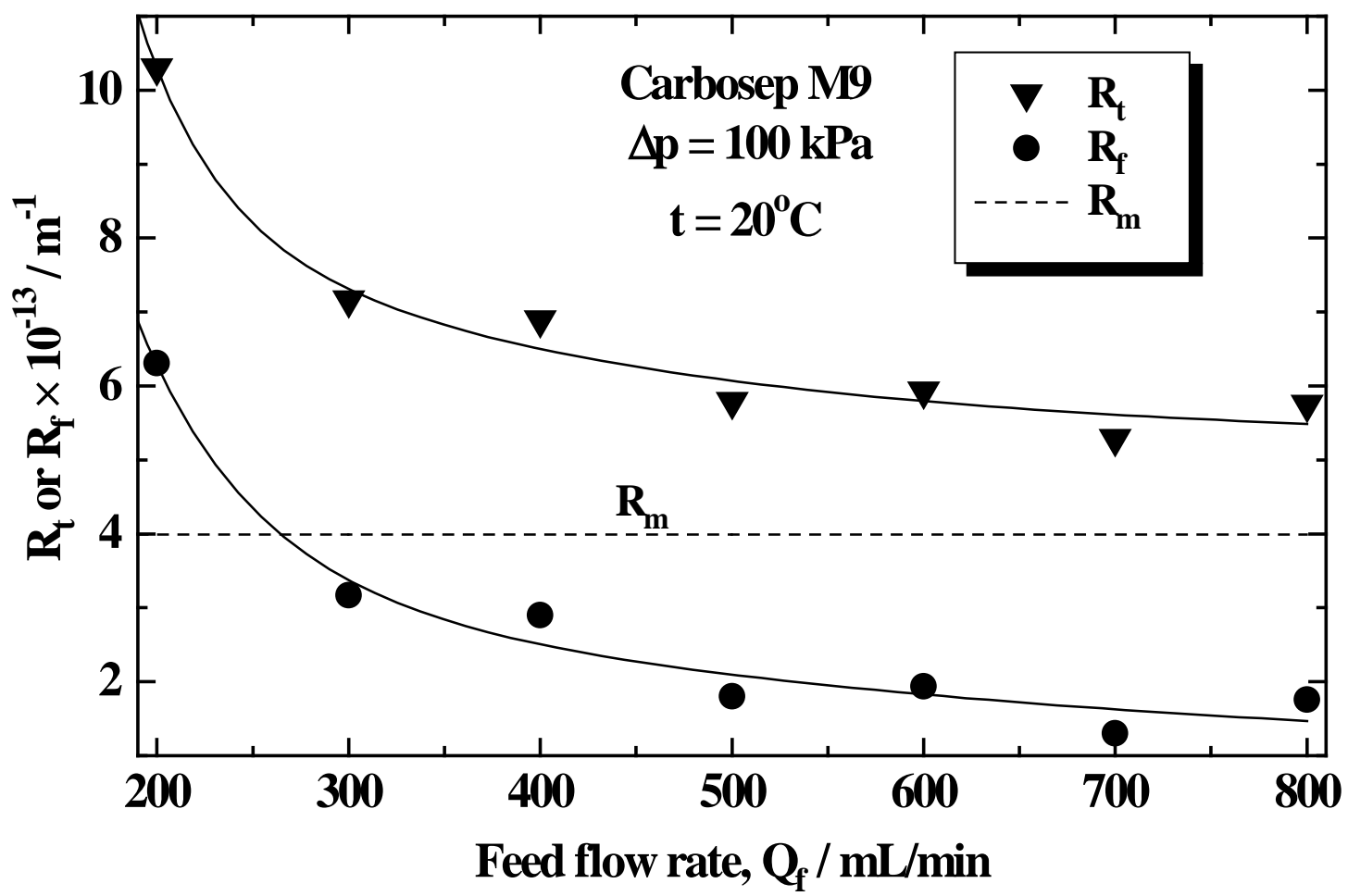

Figure 7. 


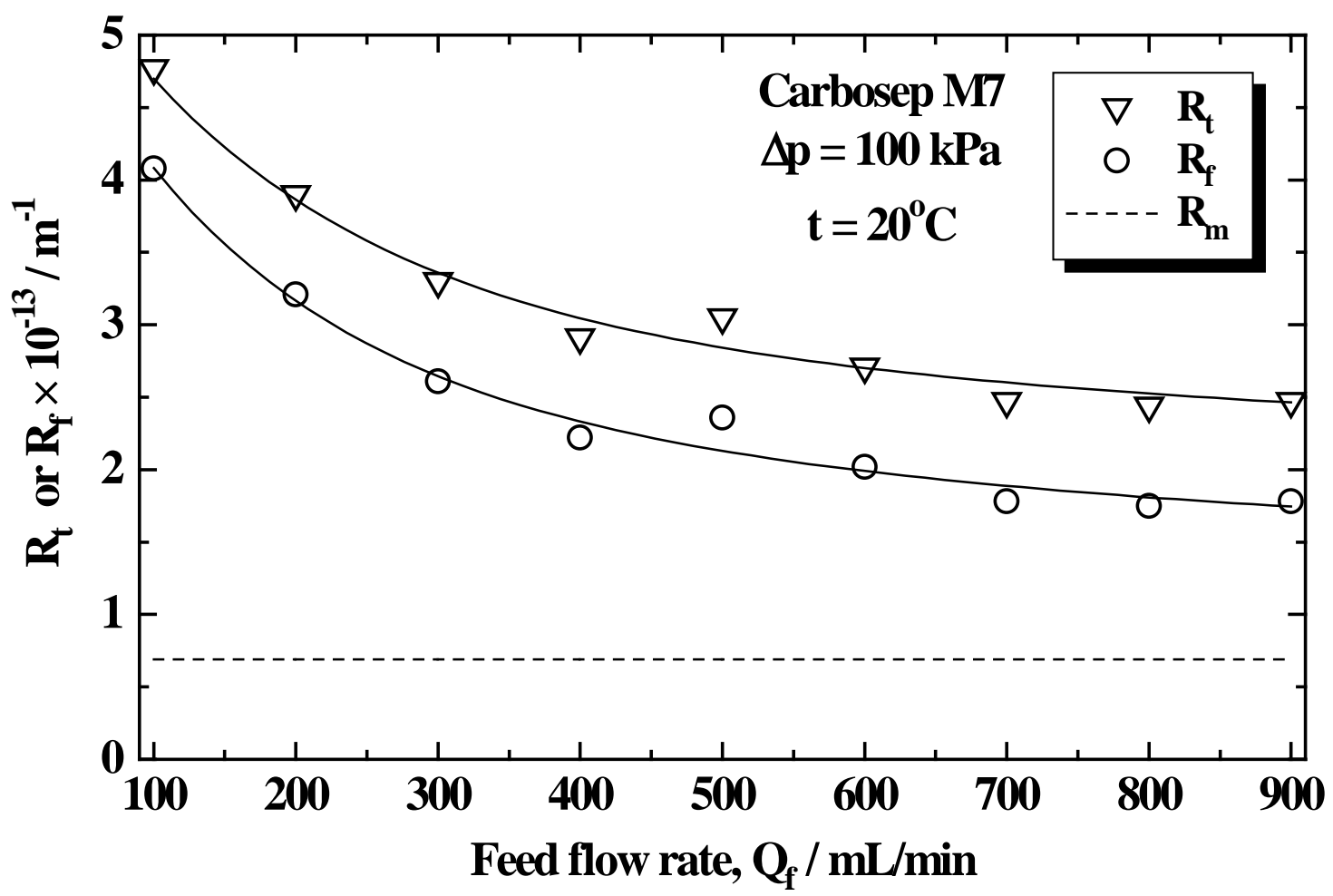

Figure 8. 


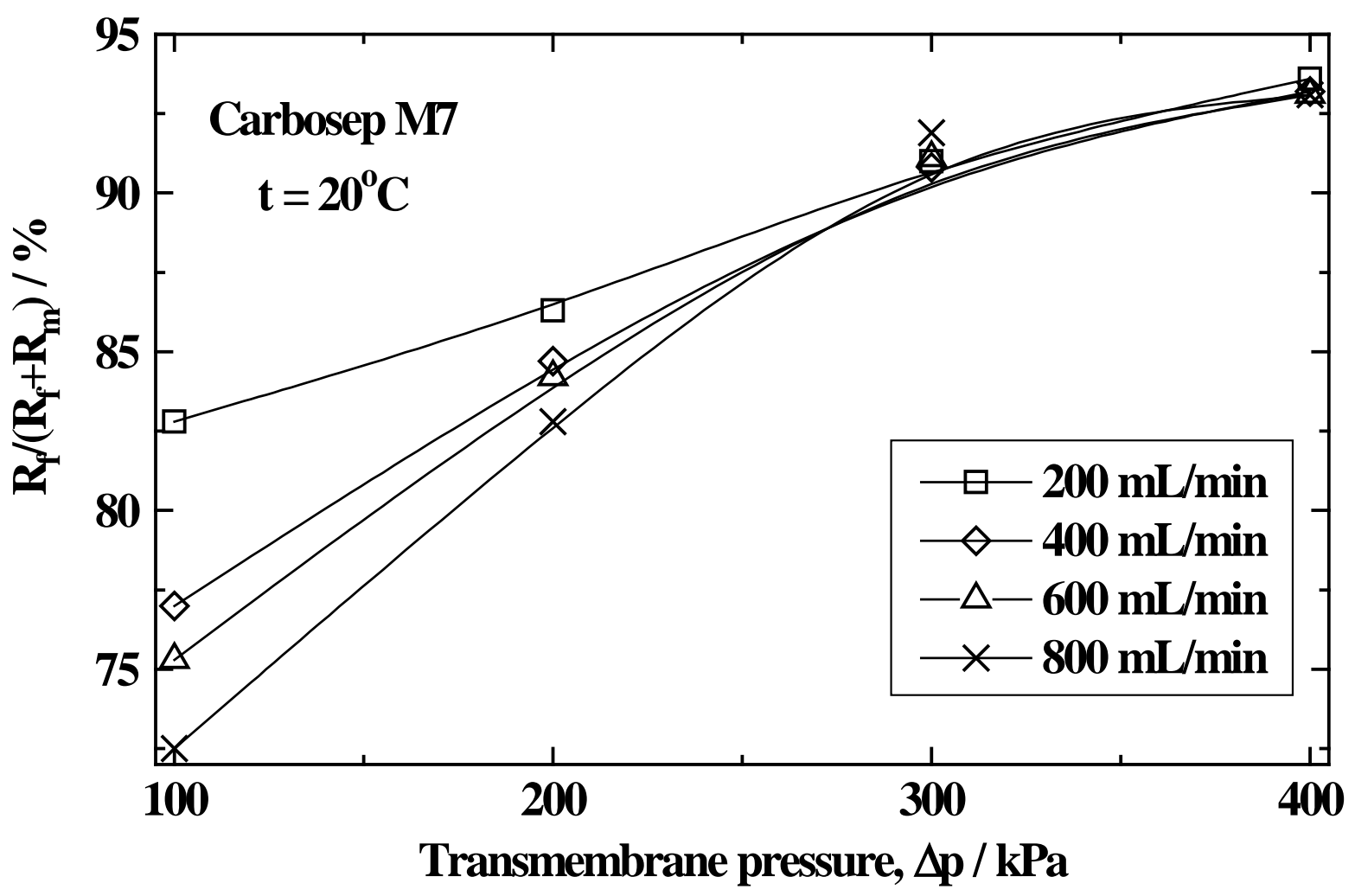

Figure 9. 